\title{
EDUCATION RELATED TO TOURISM RECEIVED BY POLISH TOURISM AND RECREATION STUDENTS IN CHILDHOOD AND ADOLESCENCE AND ITS IMPACT ON THEIR TOURISM ACTIVITY
}

\author{
ANETA OMELAN ${ }^{1}$, ELŻBIETA HUK-WIELICZUK², ROBERT PODSTAWSKI ${ }^{3}$ \\ University of Warmia and Mazury in Olsztyn, Faculty of Environmental Sciences, Department \\ of Tourism, Recreation and Ecology ${ }^{1}$, Division of Physical Education and Sport ${ }^{3}$ \\ Józef Piłsudski University of Physical Education in Warsaw, Faculty of Physical \\ Education and Sport in Biała Podlaska, Division of Health Education ${ }^{2}$
Mailing address: Aneta Omelan, Faculty of Environmental Sciences, Department of Tourism, Recreation and Ecology, 5 M. Oczapowskiego Street, 10-719 Olsztyn, tel.: +48 89 5233456, fax: +48 89 5233969, e-mail: aneta.omelan@uwm.edu.pl

\begin{abstract}
Introduction. If activity related to tourism is planned effectively and performed in a responsible way, it can satisfy many human needs. In order to make it possible for members of modern society to fully benefit from tourism, however, it is necessary to undertake action aimed at promoting tourism, fostering its development, stimulating the need to travel, and helping tourists adopt certain habits. The aim of the study was to collect information concerning the impact of family, school, and community organisations on the tourism activity of students of tourism and recreation. Material and methods. The study involved 289 students of an undergraduate programme in tourism and recreation offered by the Faculty of Environmental Sciences at the University of Warmia and Mazury in Olsztyn. The study was conducted using a specially designed diagnostic survey on "Education in tourism". Results. More than 71\% of the students surveyed engaged in tourism with their parents in childhood and adolescence, and those living in the city did so more frequently. Only one in four students said that during family trips visiting sights and attractions was combined with active tourism. As far as school trips are concerned, the respondents did take part in them, but these were mostly one-day sightseeing trips, aimed at developing their knowledge about the country, during which pupils do not undertake intense physical activity. More than half of the respondents participated in summer camps for children and adolescents. An overwhelming majority of the respondents stated their parents had had the greatest influence on their tourism activity, while community organisations and schools had had the smallest impact in this respect. Conclusion. Most of the students surveyed undertook tourism-related activities which were organised for them by different persons; thus, they received some education in tourism during childhood and adolescence. Since students of tourism and recreation will have an influence on tourism in Poland in the future, provided they work in the tourism sector, they should be prepared to promote tourism which offers a range of different benefits, not only educational ones.
\end{abstract}

Key words: tourism activity, students, family, school, community organisations

\section{Introduction}

Tourism is a form of leisure time activity which is appreciated and undertaken by millions of people in the world. If this activity is planned well and carried out in a responsible way, it can satisfy many human needs. It is worth emphasising that this activity may be continuous, as tourism can be performed during a person's whole life and can play an important and varying role in different stages of their life. In order to make this possible for more members of society, it is necessary to promote tourism, foster its development, activate their need to travel, and help them develop certain good habits.

Education in tourism can be implemented in a comprehensive manner on different overlapping levels, with consideration of social conditions, which to a large extent determine the structure, nature, and continuity of tourist and recreational behaviour. This behaviour is influenced by so called "reference groups", that is groups or communities whose opinions and behaviour impact the attitudes and reactions of an individual and determine social roles [1,2]. These groups include, among others, family, school, and child and youth organisations [3, $4,5,6,7]$. The issue of how and to what extent tourism education is provided to children and youth in Poland and what its effects are will be discussed in the remaining part of the article based on the empirical data collected. The study was conducted among students of tourism and recreation studying at the University of Warmia and Mazury in Olsztyn. This group was selected for the study since it was assumed that, due to the fact that they had chosen this programme of studies, these persons were particularly interested in spending their free time outside of their place of residence. The habits and experiences of these persons related to travelling may have a significant impact on the activities they organise for tourists in the future, in particular, as may be presumed, those visiting Warmia and Mazury, a region which clearly needs such experts. Thus, it was interesting to determine who or what and to what extent had stimulated the respondents' interest in tourism. The authors decided to investigate the groups which seem to have the 
most substantial impact on the attitudes that children and adolescents have towards tourism. An examination of the relevant literature revealed that although much information is available concerning education in tourism, there are no articles based on up-to-date empirical data that would give a comprehensive picture of the issue in question. Based on an analysis of studies which address some aspects of the issue, it seems that many researchers have investigated tourism activity organised by schools and families. However, there are few studies concerning the role of summer camps for children and adolescents and tourist organisations in shaping tourism-related habits.

For this reason, the aim of the study was to collect information concerning the impact of family, school, and community organisations on the tourism activity of students of tourism and recreation. The study focused on the educational activity of these three groups aimed at developing positive attitudes towards tourism.

The following research questions were posed:

1. Was tourism undertaken by the families of the respondents?

2. Did the respondents participate in tourism activities organised by their schools and community organisations?

3. Did the respondents take part in summer camps for children and adolescents?

4. Has the tourism activity of the respondents been determined by the education provided by institutions which are to deliver it?

\section{Material and methods}

The study involved 289 students (of three different generations) completing an undergraduate programme in tourism and recreation offered by the Faculty of Environmental Sciences at the University of Warmia and Mazury in Olsztyn. All of them were full-time students. The results showed that the programme tends to be taken by women, since as many as $71.63 \%$ of the respondents were female. As far as the place of residence of the respondents is concerned, most of them (38.41\%) lived in cities with up to 100,000 inhabitants. The remaining respondents came from the countryside (35.29\%) and cities with more than 100,000 inhabitants $(26.30 \%)$. When it comes to the respondents' financial situation, almost half of them $(46.71 \%)$ declared it was average, and a similar number $(49.83 \%)$ saw it as good or very good, while the remaining respondents said they were in a difficult financial situation.

The method used in the study was a diagnostic survey. The instrument employed was an original questionnaire regarding "Education in tourism", which contained 18 questions concerning the respondents' participation in tourism-related activities organised by their families, schools, and community organisations, as well as those offered in the form of camps for children and adolescents.

\section{Results}

The education a person receives at home and the social environment they live in have a significant impact on their attitude towards tourism and can contribute to their developing a keen interest in it. A "family model of travelling", that is one where the entire family is involved in travelling, is considered one of the best ways of fostering a pro-tourism attitude [5]. For this reason, the respondents were asked whether or not they travelled with their parents in childhood and adolescence. As many as $71.26 \%$ of the students (206 persons) gave a positive answer to this question (tab. 1).
Table 1. Travelling with the family and the respondents' place of residence (\%)

\begin{tabular}{|c|c|c|c|c|c|c|}
\hline Question & $\begin{array}{l}\text { An- } \\
\text { swer }\end{array}$ & $\begin{array}{c}\begin{array}{c}\text { Country- } \\
\text { side }\end{array} \\
\mathrm{N}=102 \\
\end{array}$ & $\begin{array}{c}\text { City }> \\
100,000 \\
\text { inhabitants } \\
\mathbf{N}=111\end{array}$ & $\begin{array}{c}\text { City }< \\
100,000 \\
\text { inhabitants } \\
N=76\end{array}$ & $\begin{array}{c}\text { Total } \\
N= \\
289\end{array}$ & $\begin{array}{c}\text { Depend- } \\
\text { ence }\end{array}$ \\
\hline \multirow{2}{*}{$\begin{array}{l}\text { Did you } \\
\text { travel } \\
\text { together } \\
\text { with your } \\
\text { parents? }\end{array}$} & Yes & 55.88 & 79.28 & 80.26 & 71.26 & \multirow{2}{*}{$\begin{aligned} \chi^{2} & =18.278 \\
p & =0.000\end{aligned}$} \\
\hline & No & 44.12 & 20.72 & 19.74 & 28.72 & \\
\hline
\end{tabular}

Source: own research.

It seemed important to determine to what extent travelling together with the family was dependent on certain social factors, the first one being the place of residence. The dependence of family travel on the respondents' place of residence was significant, as the proportions of individuals in particular groups were different (tab. 1). The respondents who lived in cities travelled more with their family when they were younger than those who came from the countryside. This difference may have been due to the type of work performed by persons living in the countryside, which makes it more difficult for them to travel, especially with the entire family. Their decision not to travel could also have been influenced by limited access to tourist services and products or a smaller need to travel.

Another factor impacting the decision to travel is the family's financial situation, which, if difficult, can limit this activity, particularly for the whole family. The study showed that family travel depended significantly on the respondents' financial situation, as the proportions of individuals in particular groups were different (tab. 2). The families that had a better financial situation travelled more. Although being in a difficult financial situation may not prevent persons who do not have a family from travelling, families in this situation tend to react differently and focus more on satisfying their basic needs.

Table 2. Travelling with the family and the respondents' financial situation $(\%)$

\begin{tabular}{|c|c|c|c|c|c|c|}
\hline Question & $\begin{array}{c}\text { An- } \\
\text { swer }\end{array}$ & $\begin{array}{c}\text { Good } \\
\text { financial } \\
\text { situation } \\
\mathbf{N}=144\end{array}$ & $\begin{array}{c}\text { Average } \\
\text { financial } \\
\text { situation } \\
\mathbf{N}=\mathbf{1 3 5}\end{array}$ & $\begin{array}{c}\text { Difficult } \\
\text { financial } \\
\text { situation } \\
\mathbf{N}=\mathbf{1 0}\end{array}$ & $\begin{array}{c}\text { Total } \\
\mathbf{N}= \\
\mathbf{2 8 9}\end{array}$ & Dependence \\
\hline $\begin{array}{c}\text { Did you } \\
\text { travel } \\
\text { together } \\
\text { with your } \\
\text { parents? }\end{array}$ & Yes & 79.17 & 63.70 & 60.00 & 71.26 & \multirow{2}{*}{$\begin{array}{l}\chi^{2}=8.78 \\
\mathrm{p}=0.012\end{array}$} \\
\cline { 2 - 6 } & No & 20.83 & 36.30 & 40.00 & 28.72 & \\
\hline
\end{tabular}

Source: own research.

An important factor influencing a child's attitude towards tourism is their involvement in particular types of tourism. If tourism is to fulfil its recreational and preventive function, so that it is an element of a healthy lifestyle, it needs to be implemented in a way that is good for one's health.

Less than half of the students surveyed declared that they spent their time in a passive way when away with their parents, and $25 \%$ of them mainly did sightseeing without engaging in too much physical effort (tab. 3). These ways of spending one's free time do not have many health benefits and are not in line with the model of tourism that helps maintain a healthy style which is currently being promoted. The remaining respondents who travelled with their parents engaged in active tourism and professional tourism (requiring not only being in good 
physical condition, but also having special skills and often being able to use special equipment) or in sightseeing combined with physical activity. This may indicate that Polish families tend not feel the need to be active, even when travelling.

Table 3. Leisure time activities undertaken when travelling with the family (\%)

\begin{tabular}{|c|c|c|}
\hline Question & Answer & $\mathbf{N}=\mathbf{2 0 6 *}$ \\
\hline \multirow{3}{*}{$\begin{array}{c}\text { How did you and your family } \\
\text { most frequently spend your } \\
\text { time when on holiday? }\end{array}$} & In a passive way & 44.00 \\
\cline { 2 - 3 } & $\begin{array}{c}\text { Sightseeing } \\
\text { Engaging in active/professional } \\
\text { tourism }\end{array}$ & 25.00 \\
\cline { 2 - 3 } & $\begin{array}{c}\text { Sightseeing and engaging in active } \\
\text { tourism }\end{array}$ & 24.00 \\
\hline${ }^{*}-\mathrm{N}=206$, since the table only presents the results for the respondents who travelled together with their family.
\end{tabular}

Source: own research.

The education provided by the family, including the one related to tourism, should be supported by schools. Nearly all $(97 \%)$ of the respondents participated in trips organised by their schools. This would indicate that Polish schools do implement the guidelines set in the core curriculum regarding tourism and developing pupils' knowledge concerning their country through sightseeing.

Table 4. Types of tourism-related events organised by the respondents' schools (\%)

\begin{tabular}{|c|c|c|}
\hline Question & Answer & N = 279* \\
\hline \multirow{2}{*}{$\begin{array}{c}\text { What types of tourism- } \\
\text { related event were organised } \\
\text { by your school the most } \\
\text { frequently? }\end{array}$} & $\begin{array}{c}\text { Mainly one-day coach trips aimed at } \\
\text { sightseeing }\end{array}$ & 84.00 \\
\cline { 2 - 3 } & $\begin{array}{c}\text { Sightseeing and active tourism } \\
\text { events }\end{array}$ & 15.00 \\
\cline { 2 - 3 } & Professional tourism events & 1.00 \\
\hline
\end{tabular}

* $-\mathrm{N}=279$ since only the respondents who had participated in events organised by their schools responded to this question.

Source: own research.

The data collected in the study (tab. 4) show that although schools organise trips, most of them are one-day trips aimed at learning about the country, during which the pupils most frequently visit historic sites and do not participate in too much physical activity. This means these trips do not offer the health benefits that active tourism does. Only a small group of respondents had the opportunity to engage in active tourism during events initiated by their school, and an even smaller one participated in professional tourism.

Schools are able to organise various kinds of tourism-related events. According to the Regulation of the Polish Minister of National Education, two hours of compulsory classes in physical education (taken per week) can be completed by "engaging in active forms of tourism, that is one or several different forms, depending on the pupils' interests and the conditions in a particular environment", and these forms include tourism involving "walking, cycling, and mountain climbing" [8]. However, as many as $67 \%$ of the respondents had never completed a physical educational class in this form.

The following question concerned taking part in camps for children and adolescents. The results revealed that more than half of the respondents (58\%, 168 persons) participated in summer camps when they were younger, and $36 \%$ of the respondents did so four times and more. Tables 5-6 contain information concerning the dependence of the respondents' participation in this form of tourism on their financial situation and place of residence.

The results of the study showed that the financial situation of the respondents was not the deciding factor when it came to their participation in summer camps. Considering the fact that camps for children and adolescents are relatively expensive [9], this result may seem quite surprising. However, it should be mentioned that in Poland such camps are often subsidised (sometimes fully) by the institutions employing the parents and by community organisations. That is why, unlike family trips, camps for children may be less of a financial burden for the family.

Table 5. Participation in summer camps and the respondents' financial situation (\%)

\begin{tabular}{|c|c|c|c|c|c|c|}
\hline Question & $\begin{array}{l}\text { An- } \\
\text { swer }\end{array}$ & $\begin{array}{l}\text { Good } \\
\text { financial } \\
\text { situa- } \\
\text { tion }\end{array}$ & $\begin{array}{c}\text { City > } \\
100,000 \\
\text { inhabitants } \\
N=111\end{array}$ & $\begin{array}{c}\text { City }< \\
100,000 \\
\text { inhabitants } \\
N=76\end{array}$ & $\begin{array}{l}\text { Total } \\
N= \\
289\end{array}$ & $\begin{array}{l}\text { Depend- } \\
\text { ence }\end{array}$ \\
\hline \multirow{2}{*}{$\begin{array}{c}\text { Did you } \\
\text { par- } \\
\text { ticipate in } \\
\text { summer } \\
\text { camps? }\end{array}$} & Yes & 62.50 & 54.14 & 50.00 & 71.26 & \multirow{2}{*}{$\begin{array}{l}\chi^{2}=2.27 \\
p=0.320\end{array}$} \\
\hline & No & 37.50 & 45.86 & 50.00 & 28.72 & \\
\hline
\end{tabular}

Source: own research.

Table 6. Participation in summer camps and the respondents' place of residence (\%)

\begin{tabular}{|c|c|c|c|c|c|c|}
\hline Question & $\begin{array}{c}\text { An- } \\
\text { swer }\end{array}$ & $\begin{array}{c}\text { Country- } \\
\text { side }\end{array}$ & $\begin{array}{c}\text { City } \mathbf{3} \\
\mathbf{1 0 0 , 0 0 0} \\
\text { inhabitants } \\
\mathbf{N}=\mathbf{1 1 1}\end{array}$ & $\begin{array}{c}\text { City }< \\
\mathbf{1 0 0 , 0 0 0} \\
\text { inhabitants } \\
\mathbf{N}=\mathbf{7 6}\end{array}$ & $\begin{array}{c}\text { Total } \\
\mathbf{N}= \\
\mathbf{2 8 9}\end{array}$ & $\begin{array}{c}\text { Depend- } \\
\text { ence }\end{array}$ \\
\hline $\begin{array}{c}\text { Did you } \\
\text { par- } \\
\text { ticipate in } \\
\text { summer } \\
\text { camps? }\end{array}$ & Yes & 52.94 & 72.07 & 80.26 & 80.26 & $\begin{array}{c}\chi^{2}=16.55 \\
\mathbf{p}=0.000\end{array}$ \\
\cline { 2 - 7 } & 44.06 & 27.93 & 19.74 & 19.74 & \\
\hline
\end{tabular}

Source: own research.

It was found that the respondents living in cities participated in summer camps for children and adolescents much more often than those from the countryside. This may have been due to a limited number of summer camps offered to persons living in the countryside, but also to their smaller needs related to travelling. Another important factor might have been the fact that persons living in highly urbanised areas may feel the need to send their children to a more natural environment, less affected by human activity. Children living in the countryside in the Warmia and Mazury region, on the other hand, have direct access to a healthy, natural environment.

Based on the results of the current study, it can be assumed that summer camps are popular with Polish families, and thus they can have a considerable impact on the attitudes and habits of children and adolescents. Table 7 shows what activities the respondents took part in during the summer camps they attended. According to their answers, the camps offered activities which were beneficial for the health of their participants, in a broad sense, and satisfied their cognitive needs.

The last element influencing the process of education related to tourism investigated in the study was the activity of tourist and youth organisations at schools. Only one in ten respondents declared that a Polish Tourist and Sightseeing Society club was active at their school (tab. 8), and only 16 respondents joined such a club when at school. The study also showed 
that in a small number of schools attended by the respondents $(13 \%)$ other youth organisations promoting spending leisure time outside of one's place of residence were active.

Table 7. Main activities engaged in during the summer camps attended by the respondents (\%)

\begin{tabular}{|c|c|c|}
\hline Question & Answer & $\mathbf{N}=\mathbf{1 6 8}$ \\
\hline \multirow{2}{*}{$\begin{array}{c}\text { What were the main } \\
\text { activities you engaged } \\
\text { in during the summer } \\
\text { camps? }\end{array}$} & Outdoor physical activity & 33.00 \\
\cline { 2 - 3 } & Visiting historic and natural sites & 13.00 \\
\cline { 2 - 3 } & $\begin{array}{c}\text { Outdoor physical activity combined with } \\
\text { sightseeing }\end{array}$ & 5.00 \\
\hline
\end{tabular}

Source: own research.

Table 8. The activity of the Polish Tourist and Sightseeing Society clubs at the respondents' schools (\%)

\begin{tabular}{|c|c|c|}
\hline Question & Answer & $\mathbf{N}=\mathbf{2 8 9}$ \\
\hline \multirow{3}{*}{$\begin{array}{c}\text { Was a Polish Tourist and Sightseeing } \\
\text { Society club active at your school? }\end{array}$} & Yes & 10.00 \\
\cline { 2 - 3 } & No & 68.00 \\
\cline { 2 - 3 } & I don't know & 22.00 \\
\hline
\end{tabular}

Source: own research.

The authors were also interested in determining which persons and institutions had had an impact on the respondents' tourism activity. An overwhelming majority of the respondents stated their parents had had the greatest influence on the way they engaged in tourism. Friends and acquaintances were another important group, while some of the students said their tourism activity was their own choice. Community organisations and schools had definitely had the smallest impact in this respect (tab. 9).

Table 9. Persons and institutions that have had the greatest impact on the respondents' tourism-related activity (\%)

\begin{tabular}{|c|c|c|}
\hline Question & Answer & $\mathbf{N}=\mathbf{2 5 6}$ \\
\hline \multirow{3}{*}{$\begin{array}{c}\text { Which person or } \\
\text { institution has had } \\
\text { the greatest impact }\end{array}$} & Parents & 44.00 \\
\cline { 2 - 3 } on your tourism & Other family members & 4.00 \\
\cline { 2 - 3 } activity? & Schools/teachers & 4.00 \\
\cline { 2 - 3 } & Friends/acquaintances & 30.00 \\
\cline { 2 - 3 } & Youth organisations & 1.00 \\
\hline
\end{tabular}

Source: own research.

\section{Discussion}

The results of the study showed that an overwhelming majority of the respondents engaged in tourism with their families when they were younger. According to the findings of the Global Advisor survey organised by Ipsos in 24 countries around the world, trips for "families with children" are seen as the most attractive form of travelling by $24 \%$ of Poles [10]. Such holiday trips are more popular with persons from Indonesia (39\%) or Brazil (29\%) and less popular among the French (13\%) and Russians (14\%). The study also confirmed that whether or not the respondents travelled together with their families depended on their place of residence and financial situation. The latter was mentioned as a significant determinant of the tour- ism activity of families among others by Kowalczyk-Anielewicz and Włodarczyk [4]. Although the fact that the families of so many respondents spent time travelling with them deserves to be appreciated, it should be emphasised that they did not spend their free time together in an active way: most often they spent it in a passive way or did sightseeing without engaging in much physical activity. As stated by Tadeusz Łobożewicz [11], "if tourism is to fulfil the goal of enhancing the physical condition of people who do not exert intense physical effort in their everyday life, it is insufficient for them simply to engage in tourism in the form of trips and stays outside of their place of residence; they should engage in physical activity that causes their pulse and respiratory rate to increase". Thus, in order for parents and children to fully benefit from tourism, the parents should choose forms of tourism which require physical effort, namely active and professional tourism, and the stay outside of the place of residence should involve recreation in a broad sense. These statements are confirmed by a range of research studies [12, 13, 14]. Tourism can help compensate for an insufficient amount of physical activity in everyday life, reduce stress, and prevent such civilisation diseases as obesity, diabetes, and atherosclerosis [15]. The parents of the respondents failed to make use of all the benefits offered by tourism, and most of the parents did not show their children how to engage in tourism in a beneficial way. It is likely that they followed the habits of their own families in this respect. As emphasised by Kowalczyk-Anioł and Włodarczyk [4], inheriting and creating models of behaviour related to tourism plays an important role in the tourism activity of the entire family. For this reason, it is important for the models, experiences, and traditions in the family to be of value. However, Polish tourists mainly spend their time away from home in a passive way, and only a small percentage of them engage in active and professional tourism [16]. This passive model typical of Polish families was present in the families of the respondents, and this has undoubtedly had an impact on the type of tourism they have engaged in.

As far as tourist activity organised by schools and tourist organisations is concerned, it is worth stressing that nearly all of the respondents took part in events organised by the schools they attended. Unfortunately, similarly as was the case with family tourism, it seems that the schools did not make full use of tourism to educate their pupils and improve their health. A vast majority of the respondents declared that their schools organised mainly one-day sightseeing trips by coach, aimed at broadening the pupils' knowledge concerning their country. Similar results in this respect were obtained in the study conducted by Dąbrowska et al. [17]. It is likely that teachers who plan such trips do not have the competences needed to prepare a trip which would be more beneficial for the pupils. It could also be presumed that most teachers are not aware of the benefits that tourism offers for the comprehensive development of children and adolescents, are unable to make use of these benefits, and do not appreciate its role as a special element of the teaching process.

Few of the respondents engaged in active and professional tourism at school, despite the fact that every school has teachers of physical education who are able to organise events related to these forms of tourism. It is graduates of universities of physical education who - owing to the type of education they have received, their skills, and often their personal interest in sports and travelling - should be the most predisposed to initiate tourism activity which fosters the pupils' comprehensive development, that is active and professional tourism. Regrettably, as shown by the findings of the current study, Polish teachers of physical education seem not to be making use of their potential in this respect.

To sum up the role school plays in the process of educating pupils in beneficial tourism, it can be stated that the model 
of school tourism in Poland is to a large extent similar to the one of mass tourism: it focuses on cultural and natural values, without offering opportunities for physical activity. Therefore, during events organised by schools, Polish pupils do not have a chance to spend their free time in an active way and mostly engage in common leisure time activities which are not advantageous for their health. Adult tourists make their own choice regarding the types of travel and tourism they engage in and are responsible for the effects of this choice, but with school tourism it is the teachers who are responsible for the effect it has on children and adolescents. The teachers are the ones who decide on the goal of a particular event and manner of organising it. Unfortunately, these goals seem to be more geographically than pedagogically oriented. In such a situation school tourism is a waste of time, money, and the chance to stimulate pupils in a positive way [18].

As for tourist organisations, the ones in Poland have a long tradition, and, what is important, they mostly promote active and professional tourism. However, the findings of this study would indicate that currently they do not have a great impact on the tourism activity of children and adolescents. In most of the schools attended by the respondents, the clubs of the Polish Tourist and Sightseeing Society were not active, and other organisations which promote tourism were only active in a few schools. Taking into account the vast experience of such organisations as the Polish Tourist and Sightseeing Society, the Polish Youth Hostel Association, and the Polish Scouting and Guiding Association, this means that young people are missing an important opportunity to engage in tourism.

Another significant element of educating young people in tourism can be their participation in organised leisure time activities for children and adolescents. More than half of the respondents attended summer camps, and most of them did so four times and more. The respondents' participation is such events was dependent on their place of residence: children and adolescents from the countryside participated in this form of tourism less often.

The camps that the respondents took part in when they were younger focused particularly on outdoor physical activity, which seems to be a traditional feature of such events. In the years 1986-1990 research was carried out regarding the programmes in physical culture that were being offered by Polish summer camps [19]. The authors of this research found that these activity programmes were appropriate and corresponded with modern theory in physical education, although they were not fully implemented. The authors also established that the stay at the camps and physical activity were appreciated by their participants and regarded as attractive. It can thus be stated that, as was the case in the past, summer camps seem to be fulfilling their functions well, including the health-promoting function which is related to compensating for insufficient physical activity in the everyday life of children and adolescents.

When asked which persons or institutions had had the greatest impact on the tourist activity of the respondents, almost half of them indicated that these were their parents or family members. This result confirms that the family has a considerable influence on the attitudes of children towards tourism, which should be taken advantage of by parents in order to transmit the most valuable models of spending one's free time outside of one's place of residence. The second most important group in this respect were friends and acquaintances. This answer may have been due to the young age of the respondents; they probably spend most of their time with friends, who influence their behaviour. On the other hand, very few respondents (only 4\%) mentioned schools as significant in fostering a positive attitude towards tourism. Even fewer mentioned tourist organisations, which seemed to be almost completely inactive among Polish pupils. Interestingly, none of the respondents saw summer camps as a form of tourism that had impacted their interest in tourism. This finding may be seen as surprising since, as mentioned before, numerous respondents participated in these events (and they did so frequently), and these events seemed to be considerably more beneficial, especially when it comes to health, than the forms of family and school tourism the respondents engaged in.

\section{Conclusion}

Most of the students surveyed undertook tourism-related activities which were organised for them by different persons; thus, they received some education in tourism during childhood and adolescence. Since students of tourism and recreation who work in the profession will have an influence on tourism in Poland in the future, it is recommended that they be prepared to promote tourism which offers many different benefits, not only educational ones. The actions of these future tourism experts may impact the physical condition of Polish people, and thus this issue is of importance to society. The findings of the current study indicated that some of the respondents did not have the habit of spending their free time outside of their place of residence in an active way. They did not develop this habit in the family or at school, nor were they influenced by youth organisations. That is why the responsibility for teaching future employees of the leisure sector how tourism should be organised so that it offers the greatest possible benefits rests with the faculty teaching the tourism and recreation programme.

The findings of the current study confirm that Polish people mainly spend their leisure time in a passive way when they engage in tourism organised both by their families and community organisations. Valuable models of tourism represented for instance by the Polish Tourist and Sightseeing Society do not impact too many Polish people. Although changing these unhealthy habits on all levels of tourism education seems to be a great challenge which requires taking well planned and systematic action, only in this way can future generations be encouraged to travel in a way that is beneficial for their health in a broad sense.

\section{Literature}

1. Krzymowska-Kostrowicka A. (1997). Geo-ecology of tourism and recreation. Warsaw: PWN. [in Polish]

2. Pritchard A., Morgan N., Ateljevic I. (2011) . Hopeful tourism. A New Transformative Perspective. Annals of Tourism Research 38(3), 941-963.

3. Kawula S., Brągiel J., Janke A., (1997). Issues in family pedagogy. Torun: Wydawnictwo Adam Marszałek. [in Polish]

4. Kowalczyk-Anioł J., Włodarczyk B. (2011). Family tourism - definition and scope. In J. Śledzińska, B. Włodarczyk (eds), Family tourism and prosocial behaviour (pp. 9-25). Warsaw: PTTK Kraj. [in Polish]

5. Turos L. (1999). Introduction to tourism education. Warsaw: Ypsylon. [in Polish]

6. Wartecka-Ważyńska A. (2007). Youth tourism and its determinants. Poznań: Wydawnictwo Naukowe UAM. [in Polish]

7. Janowski I. (2003). Sightseeing and school tourism. Kielce: Wydawnictwo Akademii Świętokrzyskiej. [in Polish]

8. Polish Ministry of National Education (2009). Regulation of the Minister of National Education on acceptable forms of completing two hours of compulsory classes in physical education. Warszawa: Dz. U. Nr 136, poz. 1116. [in Polish] 
9. Adventure holidays, Summer of 2014, a catalogue of camps for children and adolescents. Retrieved October 10, 2014 from http://issuu.com/mediterraneum/docs/kolonie_2014/2.

10. International Global Advisor survey conducted by Ipsos. Retrieved October 15, 2014 from http://www.ipsos.pl/ wakacje. [in Polish]

11. Łobożewicz T. (1985). Physical education, tourism and health. Warsaw: MON. [in Polish]

12. Dempsey J.M., Kimiecik J.C., Horn T.S. (1993). Parental influence on children's moderate to vigorous physical activity participation: An expectancy-value approach. Pediatric Exercise Science 5, 151-167.

13. Alderman B.L., Benham-Deal T.B., Jenkins J.M. (2010). Change in parental influence on children's physical activity over time. Journal of Physical Activity and Health 7(1), 60-67.

14. Alderman B.L., Benham-Deal T.B., Beighle A., Erwin H.E., Olson R.L. (2012). Physical education's contribution to daily physical activity among middle school youth. Pediatric Exercise Science 24(4), 634-648.

15. Żukowska-Kowalska K., Jóźków P., Mędraś M. (2005). Medical aspects of tourism and recreation. Wrocław: AWF. [in Polish]

16. Łaciak J. (2011). Polish people's tourism activity in 2010. Warsaw: MSiT. [in Polish]

17. Dąbrowska A., Batyk I., Kujawski. (2014). Youth tourism. Journal of Health Sciences 4(3), 97-103. [in Polish]

18. Omelan A., Romanowska A. (2012): School tourism. Wychowanie Fizyczne i Zdrowotne 5, 30-34. [in Polish]

19. Pochmurska J. (1992). Summer camps as an element of the physical education of children and adolescents. In R. Przewęda (ed.), Physical education in Poland (pp. 66-75) Warsaw: AWF. [in Polish]

Submitted: December 20, 2014

Accepted: May 12, 2015 